80,73\%), em T1. Avaliações estéticas segundo Pacientes e Periodontologistas: 9,33 e 6,17, respetivamente.

Conclusões: Dentro das limitações deste estudo - tamanho da amostra e tempo de seguimento pós-operatório - pode-se verificar que: Há discrepâncias entre as avaliações estéticas realizadas pelos Periodontologistas e pelos Pacientes. A perceção estética do paciente parece ser mais influenciada pela integração dos tecidos moles com os tecidos adjacentes e a perceção estética dos Periodontologistas parece ser mais influenciada pela quantidade de recobrimento radicular; As duas técnicas de cirurgia plástica periodontal permitem obter um recobrimento radicular com sucesso, em casos de RG unitárias, Classes I e III de Miller.

http://doi.org/10.24873/j.rpemd.2018.11.428

\section{\#117 Avaliação in vitro de cadeias elásticas quando expostas a soluções de clorexidina}

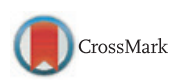

Rita Passos Gancho, Pedro Mariano Pereira*, Madalena Salema Oom, Luís Proença

Instituto Universitário Egas Moniz

Objetivos: As cadeias elásticas ortodônticas são dispositivos utilizados em ortodontia como fontes de transmissão de força aos dentes. Contudo a força das cadeias decresce ao longo do tempo, condicionando o movimento dentário. Os pacientes ortodônticos apresentam maior suscetibilidade à doença periodontal, pois a higiene oral está dificultada, exigindo um controlo mecânico e químico rigoroso. A clorexidina é um dos agentes antibacterianos mais utilizados e eficaz no controlo químico do biofilme. Existe pouca informação sobre o efeito do digluconato de clorexidina nestes materiais justificando-se a realização deste estudo. Assim, pretende-se avaliar a influência de soluções de digluconato de clorexidina, em concentrações idênticas às encontradas nos colutórios orais, na degradação das cadeias elásticas ortodônticas.

Materiais e métodos: Foram testadas cadeias elásticas de três marcas diferentes: $3 \mathrm{M}$ Unitek ${ }^{\circledR}$, Ormco ${ }^{\circledR}$, e TP Orthodonti$\mathrm{Cs}^{\circledR}$, as quais sofreram um estiramento de $50 \%$ do seu comprimento inicial, e mantidas em saliva artificial a $37^{\circ} \mathrm{C}$ simulando as condições da cavidade oral. Foram criados três grupos, o grupo controle que foi mantido durante todo o período experimental em saliva artificial e dois grupos de estudo em que as cadeias foram submersas diariamente durante 60 segundos, em duas soluções de digluconato de clorexidina (a $0.12 \%$ ou a 0.2\%). Após 0, 7, 14 e 28 dias foi avaliada a força, usando um dinamómetro, e a resistência à tração, através da máquina de testes universais.

Resultados: A submersão diária em digluconato de clorexidina a $0.12 \%$ e $0.2 \%$ afetou a força das cadeias, existindo uma deterioração superior à sofrida pelo grupo controlo $(p=0.003$ e $\mathrm{p}<0.001$ respetivamente). Verificou-se ainda, que as cadeias submersas na solução a $0.2 \%$ sofreram uma perda de força superior quando comparadas com as submersas na solução a $0.12 \%(p=0.023)$. Não se verificaram diferenças significativas na resistência à rutura das cadeias expostas à solução de $0.12 \%$ $(\mathrm{p}=0.233)$, contrariamente ao que se verificou com as cadeias submersas na solução a $0.2 \%(p=0.027)$. Verificou-se ainda diferenças significativas $(p<0.001)$ entre marcas, quer para a força quer para a resistência à rutura.

Conclusões: O uso diário de soluções de digluconato de clorexidina a $0.12 \%$ e a $0.2 \%$ parecem interferir na força das cadeias elásticas ao longo do tempo, contudo apenas a solução a $0.2 \%$ parece afetar a resistência à rutura.

http://doi.org/10.24873/j.rpemd.2018.11.427

\#118 Avaliação in vitro de cadeias elásticas quando expostas a soluções de flúor

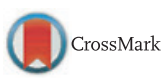

Rita Passos Gancho*, Pedro Mariano Pereira, Madalena Salema Oom, Luís Proença

Instituto Universitário Egas Moniz

Objetivos: As cadeias elásticas ortodônticas são dispositivos utilizados em ortodontia como fontes de transmissão de força aos dentes. Contudo a força das cadeias decresce ao longo do tempo, condicionando o movimento dentário. Os pacientes ortodônticos apresentam maior suscetibilidade à desmineralização dentária, pois a higiene oral está dificultada, exigindo um controlo mecânico e químico rigoroso. A prescrição de flúor, através de colutórios orais, tem vindo a disseminar-se na Medicina Dentária, devido ao seu papel preventivo nessa desmineralização dentária. Existe pouca informação sobre o efeito do flúor nestes materiais justificando-se a realização deste estudo. Assim, pretende-se avaliar a influência de soluções de fluoreto de sódio, em concentrações idênticas às encontradas nos colutórios orais, na degradação das cadeias elásticas ortodônticas.

Materiais e métodos: Foram testadas cadeias elásticas de três marcas diferentes: $3 \mathrm{M}$ Unitek ${ }^{\circledR}$, Ormco ${ }^{\circledR}$ e TP Orthodonti$\mathrm{Cs}^{\circledR}$, as quais sofreram um estiramento de $50 \%$ do seu comprimento inicial, e mantidas em saliva artificial a $37^{\circ} \mathrm{C}$ simulando as condições da cavidade oral. Foram criados três grupos, o grupo controle que foi mantido durante todo o período experimental em saliva artificial e dois grupos de estudo em que as cadeias foram submersas diariamente durante 60 segundos, em soluções de fluoreto de sódio a 248 ppm ou a 500 ppm de flúor. Após 0, 7, 14 e 28 dias foi avaliada a força, usando um dinamómetro, e a resistência à tração, através da máquina de testes universais.

Resultados: A submersão diária em fluoreto de sódio a 248 e a 500 ppm de flúor afetou a força das cadeias elásticas $(p<0.001)$, existindo uma deterioração superior à sofrida pelo grupo controlo nas cadeias expostas à solução contendo 500 ppm de flúor ( $\mathrm{p}=0.001)$. O ponto de rutura não foi afetado significativamente em ambas as soluções a 500 ppm e 248 ppm de flúor ( $p=0.134$ e $p=0.114$ respetivamente). Verificou-se ainda diferenças significativas $(p<0.001)$ entre marcas, quer para a força quer para a resistência à rutura.

Conclusões: O uso diário das soluções de higiene oral de fluoreto de sódio parece interferir na degradação das cadeias elásticas, afetando a sua força ao longo do tempo, mas não parecem interferir com a resistência à tração.

http://doi.org/10.24873/j.rpemd.2018.11.426 